\title{
Community structure and recolonization by earthworms in rehabilitated ecosystems in garhwal himalayas, India
}

\begin{abstract}
Consequences of deforestation arise from site degradation leading to modification of soil properties this significantly affect both incidence and abundance of soil macro fauna. Earthworm communities are more directly altered by these changes. Endemic and exotic species co-existed in the study area following deforestation and intensive cultivation. That native species were dominant in the undisturbed sites and disturbance and degradations leads to invasion by the exotic species holds true in our study. The sites under study represented the degraded areas as none of the species reported from the present experimental plots were endemic to the region, all the species are either peregrine exotic or peregrine endemic to the area as many of the endemic species of this region probably exterminated during the last Quaternary Glaciation. The numbers of species present at our sites ranged between 2 to 5 . The presence of litter layer and lower perturbation pressure resulted in the numerical dominance of Lennogaster pussilus in the Oak forest (OF) and the higher biomass of $A$. alexandri may be because of the larger size of the earthworm. B parvus, L. pussilus and $P$. excavatus are litter-associated taxa which were more directly affected by OF clearance and the resulting decrease in available litter, thus explaining their disappearance in the changed ecosystems, however improved soil moisture and temperature as well as input of organic matter in rehabilitated agricultural land (RAL) could probably be favourable factor for decolonization and dominance of L. pussilus. A. alexandri had wider ecological amplitude occurring under all land use types as reported in our studies, conversion of two other land use types resulted in lower species diversity. Our results show that the abandoned agriculture land (AAL) remains closer to the $\mathrm{AL}(\mathrm{T})$ than to the forest because in these land use types the overall vegetation diversity remains low corresponding to a low diversification of the organic resources thus explaining the similarity between the earthworm communities in land use types. Seasonal rhythmic pattern was exhibited by all the species identified.
\end{abstract}

Keywords: deforestation, rehabilitation, earthworm community, functional guild, ecological categories, diversity index
Volume 2 Issue 2 - 2018

\section{Bhadauria T,' Saxena KG²}

'Department of Zoology, Feroze Gandhi P.G. Degree College, India

${ }^{2}$ School of Environmental Sciences, Jawaharlal Nehru University, India

Correspondence: Tuneera Bhadauria, Department of Zoology, Feroze Gandhi College, Raebareli, Uttar Pradesh, India, Tel +91 9453022105,Email tunira@gmail.com

Received: November 22, 2017 | Published: March 07, 2018

\section{Introduction}

Himalaya is a vast and diverse mountain system. Agro forestry land use covering $(20 \%)$ of geographical area of Indian Himalayas is distributed as patches in the matrix of forest covering (52\%) area. Forest based tree- crop livestock integrated farming is the predominant traditional land use in central Himalayas. ${ }^{1}$ Hill agriculture appears to be key threat to soil biodiversity and ecosystem service due to huge amount of biomass extraction to sustain live stock and produce manure for managing soil fertility and also in terms of direct loss of forest cover due to agriculture land use. ${ }^{2}$ This problem has been further accentuated by extensive deforestation and unsustainable land use causing extensive degradation of the mountains. A pilot project was carried out to restore and rehabilitate the abandoned agriculture land site and degraded forest land site through agro forestry and forestry plantations. ${ }^{3}$ Land degradation implies a decline in the useable natural resource base and therefore loss of biodiversity and ecosystem functions. The interacting functions of soil organisms and the effects of human activities in managing land for agriculture and forestry affect soil health and quality. ${ }^{4}$ Soil faunal biodiversity is an important resource for environmental monitoring and natural resource management, changes in the variety and abundance of organisms in response to ecosystem disturbance, degradation and rehabilitation provide important management information. ${ }^{5}$ Soil management options can have dramatic effects upon soil invertebrate communities. ${ }^{6,7}$ Earthworm communities are the result of both interactions between species $^{8}$ and sensitivity to ecological factors ${ }^{9}$ presence or absence of ground vegetation and changes in its composition are known to affect the composition of earthworm communities. ${ }^{10}$ This is the first systematic study where work is focused primarily on the ecological impact, the extent, causes and consequences of varying land degradation and subsequent rehabilitation strategies on earthworm fauna in Central Himalayas. Micro scale variability in earthworm community in traditional agro ecosystem will also be focused by comparing two types of micro sites viz below tree canopy from (1$3 \mathrm{~m})$ the bole and outside tree canopy (1-3m) from canopy margin. Changes in the vegetation cover (forest clearance, tree plantation) change the soil microclimate condition therefore present study also aims to analyze how these changes affected the functional guild of the earthworms.

Soil fauna vary through time as they have seasonal rhythms mainly regulated by temperature and moisture and thus constitute one of the important factors of changes in the species assemblage structure. ${ }^{11,12}$ Consequently, the way seasonal variations of earthworm communities impacted by land-use changes occurs as well as its impact on biomass 
and density of earthworms have been examined across the sampling sites.

\section{Materials and methods}

\section{a. description of study site}

The study was carried out at Banswara village located at $1200 \mathrm{~m}$ above mean sea level in Chamoli district, Garhwal (latitude $30^{\circ} 27^{\prime} \mathrm{N}$ and $79^{\circ} 5^{\prime} \mathrm{E}$ ). The climate is typical monsoon, monthly minimum and maximum temperature varying in the range of $6-21^{\circ} \mathrm{C}$ and $18-35^{\circ} \mathrm{C}$, respectively, with an average annual rainfall of $1700 \mathrm{~mm} .80 \%$ of total rain fall is received during the monsoon period of July to September (Figure 1A) (Figure 1B). Soil moisture and temperature are as presented in Figure 2(A) \& Figure 2(B). The soil is sandy loam to loamy sand in texture (Table 1) derived from felspathic quartz schists ,quartz muscovite schists and quartz chlorite schist. ${ }^{13}$ To study the impact of changed land use practices on earthworms following land uses were identified in the village Banswara.

Table I Soil characteristics of different land use/cover types in central Himalayan $( \pm S E)$, India (Average mean values for one year.Values followed by different superscript letters are significantly $(P<0.05)$ different.

\begin{tabular}{|c|c|c|c|c|}
\hline \multirow[t]{2}{*}{ Land use/cover } & \multicolumn{4}{|c|}{ Soil property } \\
\hline & $\mathrm{pH}$ & $\begin{array}{l}\text { Bulk density } \\
\qquad\left(\mathrm{g} \mathrm{cm}^{-3}\right)\end{array}$ & Organic carbon $\left(\mathrm{g} \mathrm{kg}^{-1}\right)$ & $\begin{array}{l}\text { Total nitrogen } \\
\quad\left(\mathrm{g} \mathrm{kg}^{-1}\right)\end{array}$ \\
\hline Oak forest (OF) & $6.1^{\mathrm{a}}$ & $1.1 I^{\mathrm{a}}$ & $12.6^{\mathrm{a}}$ & $1.2^{\mathrm{a}}$ \\
\hline $\begin{array}{c}\text { Microhabitat below agro forestry } \\
\text { tree patches } A L(T)\end{array}$ & $6.4^{\mathrm{a}}$ & $1.04^{\mathrm{a}}$ & $18.1^{\mathrm{b}}$ & $0.9^{\mathrm{a}}$ \\
\hline $\begin{array}{c}\text { Microhabitat without agro forestry } \\
\text { tree patches (ALWT) }\end{array}$ & $6.2^{\mathrm{a}}$ & $1.10^{\mathrm{a}}$ & $13.2^{\mathrm{a}}$ & $1.9^{\mathrm{b}}$ \\
\hline Abandoned agricultural land(AAL) & $6.4^{\mathrm{a}}$ & $1.4^{\mathrm{b}}$ & $8.6^{c}$ & $0.8^{c}$ \\
\hline Rehabilitated agricultural land (RAL) & $6.3^{\mathrm{a}}$ & $1.12^{\mathrm{a}}$ & $15.0^{\mathrm{d}}$ & $1.4^{\mathrm{d}}$ \\
\hline Degraded forest land(DFL) & $6.2^{\mathrm{a}}$ & $1.42^{\mathrm{b}}$ & $8.3^{c}$ & $0.7^{c}$ \\
\hline Rehabilitated forest land (RFL) & $5.8^{\mathrm{b}}$ & $1.14^{\mathrm{a}}$ & $12.4^{\mathrm{a}}$ & $1.7^{\mathrm{b}}$ \\
\hline
\end{tabular}

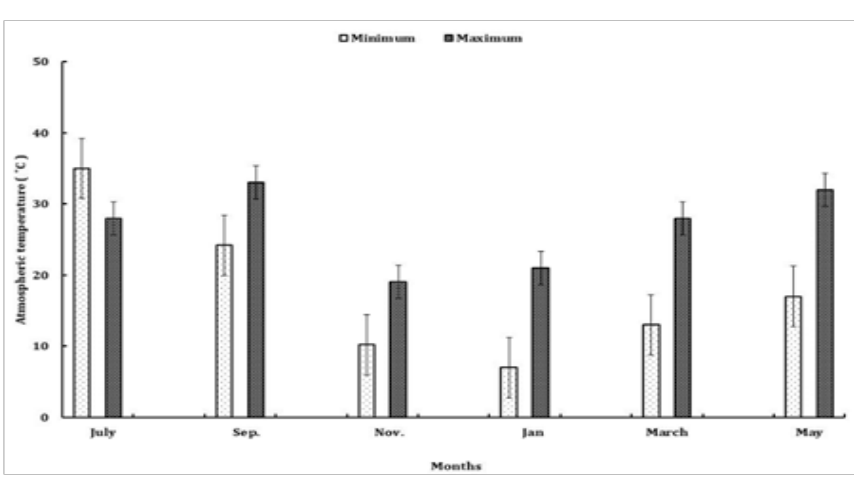

Figure I (A) Monthly maximum and minimum atmospheric temperature for study area in Garhwal Himalayas during the study period from July 2008-2009.

\section{b. Old secondary forest (OF)}

The reserved forests are unmanaged old-growth sub tropical warm temperate forest dominated by Quercus samicarpifolia, Q.floribunda Cedrus .

\section{c. Traditional rainfed farming systems}

The farming system is characterized by settled rainfed organic agriculture on terraced slope with scattered multipurpose trees

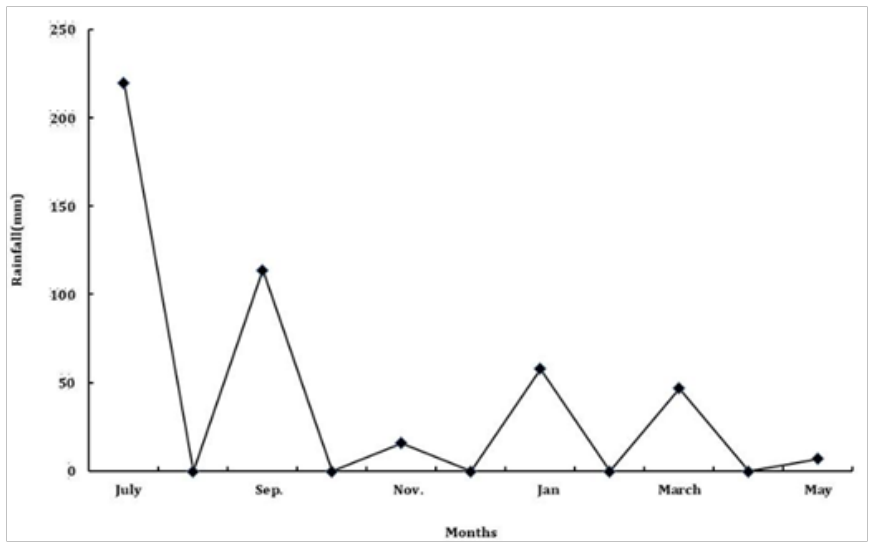

Figure I (B) Monthly Rainfall for study area in Garhwal Himalayas during the study period from July 2008-May 2009.

\section{d. Microhabitat below agro forestry tree patches AL(T)}

The sampling of soil fauna was done below was done below the tree canopy (1-3mdiameter from the bole).

\section{e. Microhabitat without agro forestry tree patches AL(WT)}

The sampling of soil fauna was done below was done below the tree canopy (1-3m from canopy margin). 


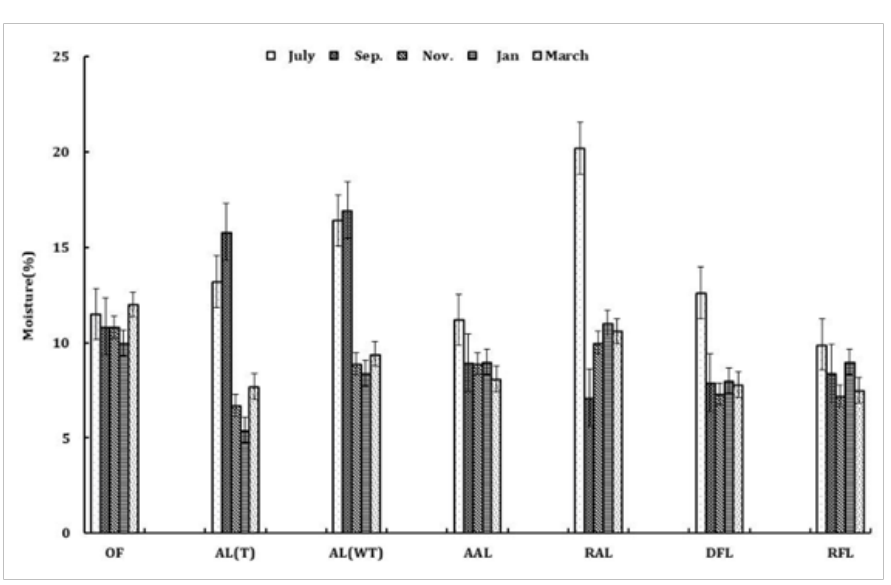

Figure 2 (A) Soil moisture (\%) under different land use.

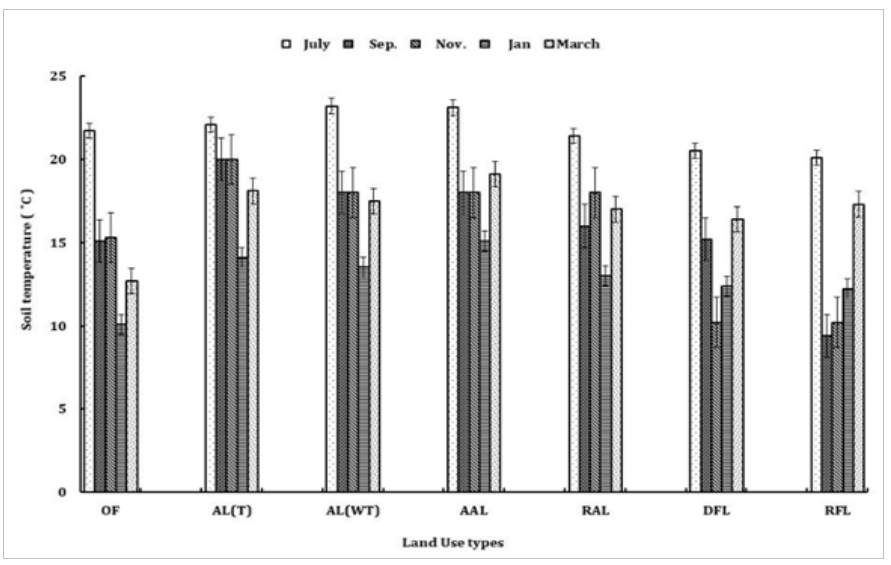

Figure 2 (B) Soil temparature $\left({ }^{\circ} \mathrm{C}\right)$ under different land use.

\section{f. Abandoned agriculture land (AAL)}

Degraded abandoned agriculture land represented the agriculture terraces which had been abandoned due to poor soil fertility status, they were degraded and exposed to uncontrolled grazing.

\section{g. Rehabilitated agriculture land (RAL)}

The rehabilitated land site was the abandoned agriculture land site where the terraces were repaired and agricultural crops were grown providing supplemental irrigation and organic manure along with the planted trees following traditional farming practices. This site was protected from grazing and other human disturbances.

\section{h. Degraded forest land (DFL)}

Degraded Forest Land represented degraded community forest land which had negligible tree cover and was exposed to uncontrolled grazing. Soils on the degraded land were considerably eroded with respect to abandoned agriculture land.

\section{i. Rehabilitated forest land (RFL)}

The Rehabilitated forest site represented the plantation of trees on degraded community forest land which had more stressful environment as compared to the RAL. This site was protected from grazing and other human disturbances.

\section{j. Experimental design}

Soil sampling: In each land use type a plot of $40 \times 50 \mathrm{~m}^{2}$ was demarcated for earthworms and for soil sampling, three composite soil samples were prepared in each experimental plot. Six $25 \mathrm{~cm} \times 25 \mathrm{~cm} \times 30 \mathrm{~cm}$ deep soil monoliths were randomly sampled from each replicate plot at regular bimonthly intervals. Each monolith was subdivided into $0-10,10-20$, and $20-30 \mathrm{~cm}$ blocks, the soil samples were air dried and sieved through a $2 \mathrm{~mm}$ sieve. A representative of the sub-sample was stored for subsequent analysis. ${ }^{14}$ Soil temperatures were recorded weekly at $0-10$ and $10-20 \mathrm{~cm}$ depths; however, the values presented here are mean monthly values for $0-10$ $\mathrm{cm}$ depth. Soil moisture was recorded every month at 0-10 and 10$20 \mathrm{~cm}$ depths, but the values presented here are mean monthly values for $0-10 \mathrm{~cm}$ depth and are expressed as \% oven dry weight at 105 ${ }^{\circ} \mathrm{C}$. Bulk density was estimated following standard methods. ${ }^{14}$ The analysis of soil texture was done using a hydrometer method, ${ }^{15}$ soil $\mathrm{pH}$ was measured as 1: 2.5 (soil: water) solution, and organic $\mathrm{C}$ through the. ${ }^{16}$ Soil $\mathrm{N}$ was analyzed using the semi-micro Kjeldahl method following the procedures described. ${ }^{17}$

Soil fauna sampling: Earthworms were sampled using the soil biology and fertility methodology (17). On each site in a plot of $25 \mathrm{~cm} \times 25 \mathrm{~cm}$ earthworms were collected at regular bimonthly intervals over a period of 12 months, i.e. between June 2007 and June 2008. Earthworms were collected from 10 sampling points 5 $\mathrm{m}$ apart along a transect with a random origin, they were extracted by hand sorting after digging a trench up to $30 \mathrm{~cm}$ deep around a $25 \mathrm{~cm} \times 25 \mathrm{~cm}$ area at each sampling point to get a soil monolith. These soil monoliths were divided into three layers $(0-10,10-20,20$ $30 \mathrm{~cm}$ ) and earthworms were extracted from each layer, they were then washed and preserved in 5\% formalin for further identification. ${ }^{17}$

i. Statistical analysis of the data: Statistical analysis was done following the biostatistical methods described in (18).

a) Significant differences in physicochemical characteristics of the soil across different sampling sites were carried out using one-way ANOVA.

b) Significant differences in the density and biomass of earthworm species across different sampling sites (interhabitat variations) were tested using non-parametric one-way ANOVA (F-test), and the New Mann Keul's multiple range test.

c) Significant differences in functional guild changes of earthworm's species in the same site and functional guild changes of earthworm species across different sampling sites were were tested using nonparametric one-way ANOVA (F-test), and the New Mann Keul's multiple range test.

d) Seasonal variations in total density and biomass of earthworm species in sampling sites were tested using the non-parametric Kruskal-Wallis test of variance and New Mann Keul's multiple range test.

e) Diversity index was calculated as Simpsons Index of Diversity

$$
D=1-\sum_{i=1}^{n} n i(n i-1) / N(N-1)
$$


Where $n i=$ number of individuals of species $\mathrm{i}$ in the sample. $\mathrm{N}=$ total number of individuals in the sample.

$\mathrm{S}=$ Number of species in the sample. $1-\mathrm{D}^{\wedge}=$ Simpsons Index of Diversity

f) The dominance value was calculated as, Dominance=Total number of individuals of a species/ Total number of individuals of all the species

g) A simplified Morisita's Index of Similarity was calculated as

$$
\frac{{ }^{2} \sum^{\mathrm{Xij} X \mathrm{Xk}}}{\left\{\left(\frac{\sum^{X^{2}}{ }^{2}}{N^{2} \mathrm{j}}\right)+\left(\sum^{\left.\left.\mathrm{X}^{2}{ }^{2} \mathrm{jk} / N^{2}{ }_{\mathrm{k}}\right) N \mathrm{NNk}\right\}}\right.\right.}
$$

Where

$\mathrm{Xij}$ is the number of individuals of species $\mathrm{i}$ in group $\mathrm{j}$

Xik is the number of individuals of species $\mathrm{i}$ in group $\mathrm{k}$

$\mathrm{N}$ is the total number of individuals in the sample $\mathrm{j}$ and $\mathrm{k}$

h) The correlation between soil parameters such as temperature, moisture and organic matter and earthworm species was calculated as a simple correlation coefficient ( $\mathrm{r}$ ). Sample standard error was calculated as the standard error of the Mean $( \pm S$ E).

i) The SYSTAT 12 software for Windows package (Systat Software Inc., San Jose, USA) was used for all statistical tests

\section{Result}

\section{a. Soil characteristics}

Soil characteristics varied under different land use types, except for RFL soil $\mathrm{pH}$ was mildly acidic in all other sites, soil bulk density was higher in AAL and DFL when compared to other land use types under study. Soil organic $\mathrm{C}\left(\mathrm{F}_{005,614}=32.9\right)$ and Nitrogen $\left(\mathrm{F}_{0.05,6.14}=\right.$ 151) varied significantly between different sites, organic $C$ was significantly higher $\left(\mathrm{F}_{0.05,6,14}=151\right)$ in $\mathrm{AL}(\mathrm{T})$ as compared to all other sites but did not vary significantly between RFL and OF, between AL (WT) and OF. Total nitrogen was significantly higher $\left(\mathrm{F}_{0.05,6,14}=\right.$ 151 ) in AL (WT) as compared to all other sites, but it did not vary significantly between AL (WT) and RFL and between AL (T) and OF. Soil organic carbon $\left(\mathrm{q}_{0.05,21,3}=3.41\right)$ and nitrogen $\left(\mathrm{q}_{0.05,21,3}=4.76\right)$ was significantly higher in AAL as compared to DFL (Table1).

\section{b. Selected attributes of sampled earthworm species across different land use types}

A total of eight species belonging to four families were recorded from land use types under study and the selected attributes of sampled earthworm species (Table 2). All the earthworm species recorded across different land use types were both peregrine endemic or peregrine exotic to the region, none of these were endemic to Garhwal Himalayas (Table 2).

\section{c. Effect of land use patterns on earthworm species richness}

Earthworm species richness did not vary significantly between the OF, AL (T) and AL (WT), but in AAL and DFL number of species was lower; however rehabilitation of these ecosystems led to increase in species number in RAL and RFL (Table 3).

Table 2 Selected attributes of sampled earthworm species across different land use types in Garhwal Himalayas

\begin{tabular}{|c|c|c|c|c|c|c|c|}
\hline Species & Color & Length*(mm) & Diameter(mm)* & Family & $\begin{array}{l}\text { Peregrine } \\
\text { Species }\end{array}$ & Native region & $\begin{array}{l}\text { Ecological } \\
\text { Catagories }\end{array}$ \\
\hline $\begin{array}{l}\text { Amynthas } \\
\text { alexandri }\end{array}$ & Dark Brown & 180 & 8 & Megascolecidae & Exotic & S.E.Asia & Endogeic \\
\hline Bimastos parvus & Dark brown & 70 & 2 & Lumbricidae & Exotic & N.America & Epigeic \\
\hline Drawida nepalensis & Light whitish & 140 & 7 & Moniligastridae & $\begin{array}{l}\text { Native } \\
\text { peregrine }\end{array}$ & $\begin{array}{l}\text { Eastern } \\
\text { Himalayas }\end{array}$ & $\begin{array}{l}\text { Endogeic/ } \\
\text { Anecic }\end{array}$ \\
\hline $\begin{array}{l}\text { Lennogaster } \\
\text { pussilus }\end{array}$ & Light brown & 50 & 2 & Octochaetidae & $\begin{array}{l}\text { Native } \\
\text { peregrine }\end{array}$ & $\begin{array}{c}\text { Middle and } \\
\text { Upper Gangetic } \\
\text { plains }\end{array}$ & Epigeic \\
\hline $\begin{array}{c}\text { Metaphire } \\
\text { anamola }\end{array}$ & Dark brown & 140 & 4 & Megascolecidae & Exotic & S.E.Asia & Endogeic \\
\hline $\begin{array}{c}\text { Metaphire } \\
\text { birmanica }\end{array}$ & $\begin{array}{l}\text { Blackish } \\
\text { brown }\end{array}$ & 160 & 4 & Megascolecidae & Exotic & Burma & Endogeic \\
\hline $\begin{array}{c}\text { Octochaetona } \\
\text { Beatrix }\end{array}$ & Light Pink & 120 & 4 & Octochaetidae & $\begin{array}{l}\text { Native } \\
\text { peregrine }\end{array}$ & $\begin{array}{c}\text { Eastern and } \\
\text { Western Plateau } \\
\text { region }\end{array}$ & Endogeic \\
\hline Perionyx excavatus & $\begin{array}{l}\text { dark violet / } \\
\text { Purple }\end{array}$ & 76 & 3 & Megascolecidae & $\begin{array}{l}\text { Native } \\
\text { peregrine }\end{array}$ & $\begin{array}{l}\text { Eastern } \\
\text { Himalayas }\end{array}$ & Epigeic \\
\hline
\end{tabular}

Measurements of largest individuals indicating the maximum achievable size

d. Changes in earthworm species composition across different land use types

Three peregrine exotics Amynthas alexandri, Bimastos parvus, Metaphire anamola and two peregrine native species Lennogaster pussilus, Perionyx excavatus were present in the OF .Conversion of the forest to agro ecosystems led to the change in the community structure with the loss of exotics Bimastos parvus and natives Lennogaster pussilus, Perionyx excavatus in AL (T) and AL (WT), but recolonisation by exotic Metaphire birmanica, Octochaetona 
beatrix and natives Drawida nepalensis occurred here. M. anamola, $M$. birmanica and $D$ nepalensis were present in AAL, however rehabilitation of degraded ecosystems RAL resulted in loss of $M$. birmanica and recolonisation by L. pussilus and A. alexandri. Only exotic $A$. alexandri and M. birmanica were present in DFL, but $A$. alexandri, M. anamola and M. birmanica .were present in RFL (Figure 3). B. parvus and P. excavatus did not recolonize any rehabilitated ecosystems whereas $A$. alexandri and $M$. anamola were absent in RAL and DFL though they were present on all the other sites under study (Table 4).

Table 3 Effect of land use patterns on earthworm species richness across different land use types in Garhwal Himalayas

$\left.\begin{array}{cc}\hline \text { Land Use Pattern } & \begin{array}{c}\text { Species } \\ \text { Number }\end{array} \\ \hline \begin{array}{c}\text { Old secondary Forest OF } \\ \text { Microhabitat below agro forestry tree patches } \\ \text { AL(T) }\end{array} & 5 \\ \begin{array}{c}\text { Microhabitat without agro forestry tree patches } \\ \text { AL(WT) }\end{array} & 5 \\ \text { Abandoned Agriculture LandAAL } & 3 \\ \text { Rehabilitated Agriculture LandRAL } & 4 \\ \text { Degraded Forest Land DFL } \\ \text { Rehabilitated Forest Land RFL }\end{array}\right)$

e. Total density and biomass of earthworm species across different land use types

Total density $\left(\mathrm{F}_{0.05,6,14}=228.24\right)$ as well as biomass $\left(\mathrm{F}_{0.05,6,14}=403.78\right)$

Table 4 Occurrence of earthworm species across different land use types in Garhwal Himalayas

\begin{tabular}{cccccccc}
\hline Species & OF & ALT & ALWT & AAL & DFL & RAL & RFL \\
\hline Amynthas alexandri & $\mathrm{Y}$ & $\mathrm{Y}$ & $\mathrm{Y}$ & $\mathrm{N}$ & $\mathrm{Y}$ & $\mathrm{Y}$ & $\mathrm{Y}$ \\
Bimastos parvus & $\mathrm{Y}$ & $\mathrm{N}$ & $\mathrm{N}$ & $\mathrm{N}$ & $\mathrm{N}$ & $\mathrm{N}$ & $\mathrm{N}$ \\
Drawida nepalensis & $\mathrm{N}$ & $\mathrm{Y}$ & $\mathrm{Y}$ & $\mathrm{Y}$ & $\mathrm{N}$ & $\mathrm{Y}$ & $\mathrm{N}$ \\
Lennogaster pussilus & $\mathrm{Y}$ & $\mathrm{N}$ & $\mathrm{N}$ & $\mathrm{N}$ & $\mathrm{N}$ & $\mathrm{Y}$ & $\mathrm{N}$ \\
Metaphire anamola & $\mathrm{Y}$ & $\mathrm{Y}$ & $\mathrm{Y}$ & $\mathrm{Y}$ & $\mathrm{N}$ & $\mathrm{Y}$ & $\mathrm{Y}$ \\
Metaphire birmanica & $\mathrm{N}$ & $\mathrm{Y}$ & $\mathrm{Y}$ & $\mathrm{Y}$ & $\mathrm{Y}$ & $\mathrm{N}$ & $\mathrm{Y}$ \\
Octochaetona Beatrix & $\mathrm{N}$ & $\mathrm{Y}$ & $\mathrm{Y}$ & $\mathrm{N}$ & $\mathrm{N}$ & $\mathrm{N}$ & $\mathrm{N}$ \\
Perionyx excavatus & $\mathrm{Y}$ & $\mathrm{N}$ & $\mathrm{N}$ & $\mathrm{N}$ & $\mathrm{N}$ & $\mathrm{N}$ & $\mathrm{N}$
\end{tabular}

Table 5 Density (Individuals $/ \mathrm{m}^{2} /$ year) and biomass $\left(\mathrm{g} / \mathrm{m}^{2} /\right.$ year) of earthworm species across different land use types in Garhwal Himalayas. Numbers followed by the same letter are not significantly different $(P<0.05)$.

\begin{tabular}{ccc}
\hline & $\begin{array}{c}\text { Density(individuals/ } \\
\mathbf{m}^{2} / \text { year) }\end{array}$ & $\begin{array}{c}\text { Biomass(g/ } \\
\mathbf{m}^{2} / \text { year) }\end{array}$ \\
\hline OF & $\mathrm{a} 97 \pm 18$ & $\mathrm{a} 79 \pm 2.7$ \\
AL(T) & $\mathrm{b} 358 \pm 25$ & $\mathrm{~b} 663 \pm 35.74$ \\
AL(WT) & $\mathrm{c} 263 \pm 21$ & $\mathrm{c} 403 \pm 16 \pm 37$ \\
AAL & $\mathrm{d} 19 \pm 1.4$ & $\mathrm{~d} 27 \pm 2.4$ \\
RAL & $\mathrm{e} 59 \pm 1.8$ & $\mathrm{e} 50 \pm 3.2$ \\
DFL & $\mathrm{f} 7 \pm 3.47$ & $\mathrm{f} 15.4 \pm 1.2$ \\
RFL & $\mathrm{d} 28 \pm 1.1$ & $\mathrm{~g} 62.5 \pm 4.1$ \\
\hline
\end{tabular}

of earthworm's varied significantly between different land use types due to changes in land use practices. Conversion of forest to agro ecosystem resulted in significantly higher density $\left(\mathrm{q}_{0.05,14,7}=122.73\right)$ and biomass $\left(\mathrm{q}_{0,05,14,7}=109\right.$ values $)$ in $\operatorname{AL}(\mathrm{T})$. Density $\left(\mathrm{q}_{0,05,14,4}=114\right)$ and biomass of earthworms $\left(\mathrm{q}_{0.05,14,4}=112\right)$ also increased significantly in rehabilitated ecosystems RAL and RFL when compared to AAL and DFL (Table 5).

\section{f. Endemic and exotics earthworm species}

The density and biomass of exotic peregrine earthworm species varied significantly between different sites (Figure 4A) (Figure 4B). These values were significantly higher in AL (T) followed by AL (WT) $\left(\mathrm{q}_{0.05,12,6}=102\right)$ and did not vary significantly between RAL, DFL and AAL. The biomass values of exotic species also did not vary significantly between OF and RFL. The density $\left(\mathrm{F}_{0.05,6,14}=211\right)$ and biomass $\left(\mathrm{F}_{0.05,6,14}=248\right)$ of endemic peregrine species also varied significantly between different sites and were significantly higher in $\mathrm{AL}(\mathrm{T})$ as compared to other sites. The biomass values of endemic species did not vary significantly between OF and AAL.

Within the same sites the density of exotic and endemic peregrine earthworm species did not vary significantly in OF, but exotic species had higher biomass $\left(t_{(2) 0.05,4}\right)=7.5$ as compared to endemics species. Exotic earthworm species were significantly more abundant $\left(\mathrm{t}_{(2) 0.05,4}=\right.$ 57.32) with higher biomass $\left(\mathrm{t}_{(2) 0.05,4}=25.5\right)$ values in $\mathrm{AL}(\mathrm{T})$ than endemic species. In AL (WT) and in AAL endemic species were more abundant numerically and had significantly higher biomass value than exotics species. Endemic species had significantly higher abundance in RAL $\left(\mathrm{t}_{(2) 0.05,4}=5.75\right)$ as compared to exotic species but biomass values of exotic and endemic earthworm species did not vary significantly in here. Endemic species were absent in DFL and RFL.

\section{g. Functional guild changes in earthworm communities}

Functional guild diversity varied under different land use types (Figure 5A) (Figure 5B), all the three functional categories were present in RAL. Anecics were absent in OF and AAL, in AL (T), AL (WT), DFL and RFL epigeic species were absent, where as in AAL only endogeics species were present. Epigeic were significantly more abundant $\left(\mathrm{F}_{0.05,2,6}=12.23\right)$ with higher biomass values $\left(\mathrm{F}_{0.05,2,6}=\right.$ 7.54 ) in OF. Both endogeics and anecics earthworm species were significantly more abundant $\left(\mathrm{F}_{0.05,2,6}=58.54\right)$ and had higher biomass values $\left(\mathrm{F}_{0.05,2,6}=42.63\right)$ at $\mathrm{AL}(\mathrm{T})$ compared to all other sites.

Within the same site, numerically epigeics formed the dominant $\left(\mathrm{F}_{0.05,2,6}=37.19\right)$ functional group under $\mathrm{OF}$ and in $\mathrm{RAL}\left(\mathrm{F}_{0.05,2,6}=\right.$ $18.54)$, whereas endogeic were dominant under $\operatorname{AL}(\mathrm{T})\left(\mathrm{F}_{0.05,2,6}=11.7\right)$, $\mathrm{AL}(\mathrm{WT})\left(\mathrm{F}_{0.05,2,6}=28\right)$ and $\operatorname{RFL}\left(\mathrm{F}_{0.05,2,6}=7.54\right)$, in AAL they were the 
only functional group present. Endogeics had significantly higher $\left(\mathrm{F}_{0.05,2,6}=19.4\right)$ biomass in OF and RAL when compared to epigeic and anecics. Anecics had lower abundance and biomass compared to other functional groups within the same sites.

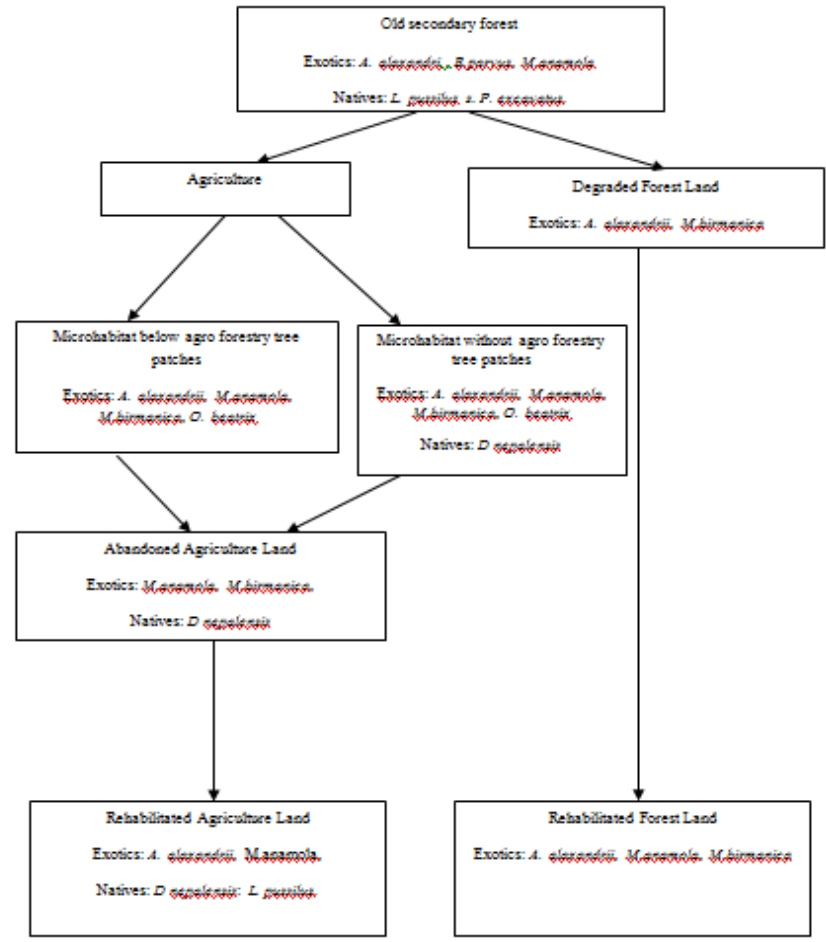

Figure 3 Changes in earthworm species composition across different land use types in Garhwal Himalayas.

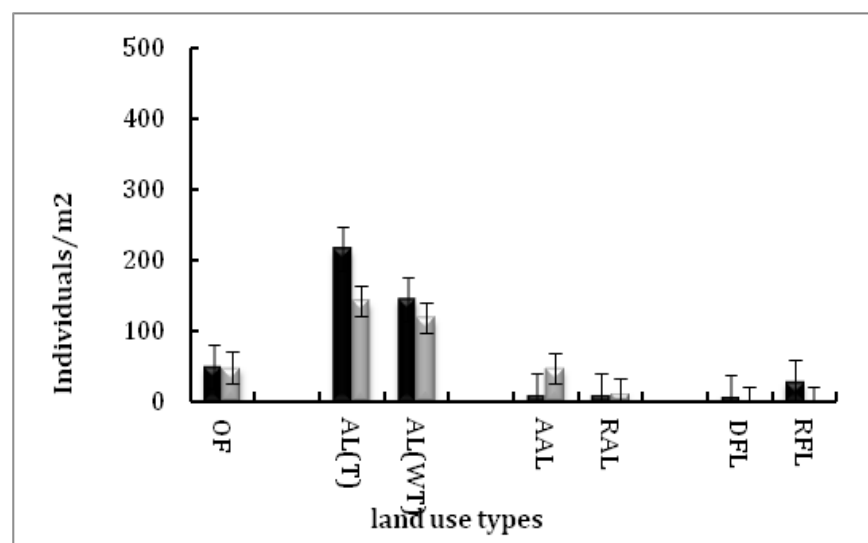

Figure 4 (A) Abundance of exotics/native earthworm species under different landuse changes.

\section{h. Seasonal variation for earthworm communities}

Seasonal variation for different earthworm species abundance and biomass (Figure $6(\mathrm{~A}-\mathrm{H})$ ).

A. Alexandri All the species showed significant seasonal variation. The density and biomass varied significantly seasonally in $\mathrm{OF}$ $\left(\mathrm{F}_{0.05,5,12}=124.6\right), \operatorname{AL}(\mathrm{T})\left(\mathrm{F}_{0.05,5,12}=133.8\right), \mathrm{AL}(\mathrm{WT})\left(\mathrm{F}_{0.05,5,12}=23.04\right)$ and RFL $\left(\mathrm{F}_{0.05,5,12}=8\right)$. It did not vary significantly in RAL and DFL.
The species had significantly higher population density $\left(\mathrm{q}_{0.05,12.6}=7.54\right)$ and biomass $\left(\mathrm{q}_{0.05,12,6}=8\right)$ during Sep at all sites except in AL(WT) and where it had higher biomass $\left(\mathrm{q}_{0.05,12,6}=7.34\right)$ during July and in RFL where species showed a minor increase in population density during January. B. parvus was present only in the oak forest and did not show any significant variation seasonally in density as well as biomass values.

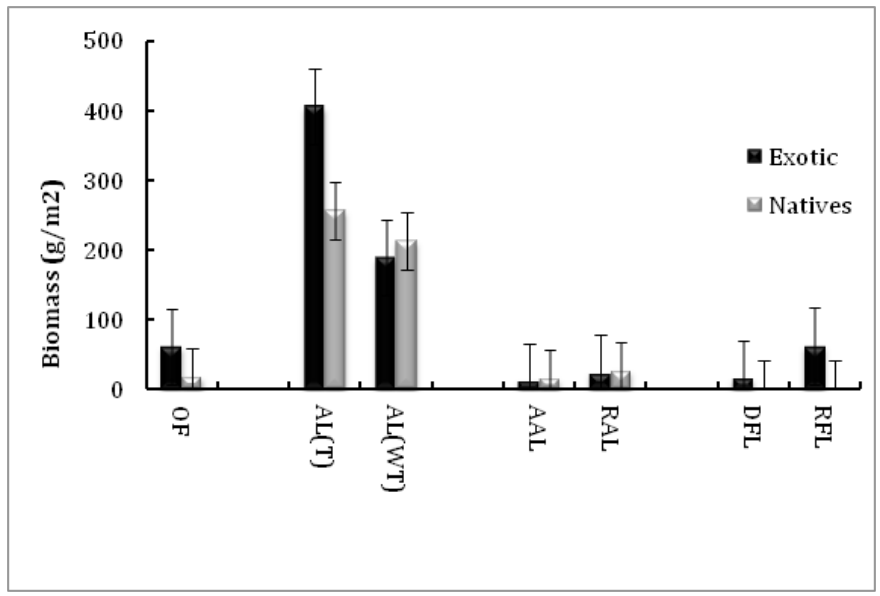

Figure 4 (B) Biomass of exotics/native earthworm species under different land use changes.

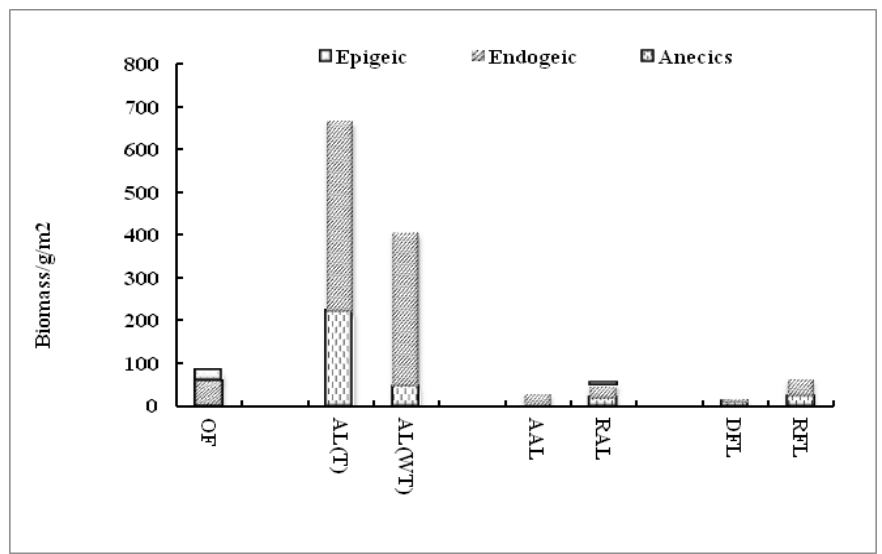

Figure 5 (A) Functional categories of earthworms under different land use types.

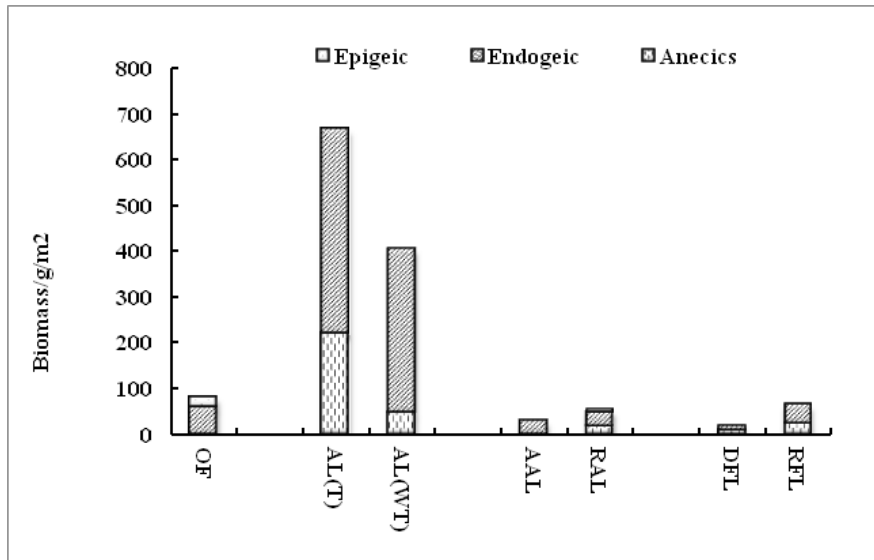

Figure 5 (B) Functional categories of earthworms under different land use types. 

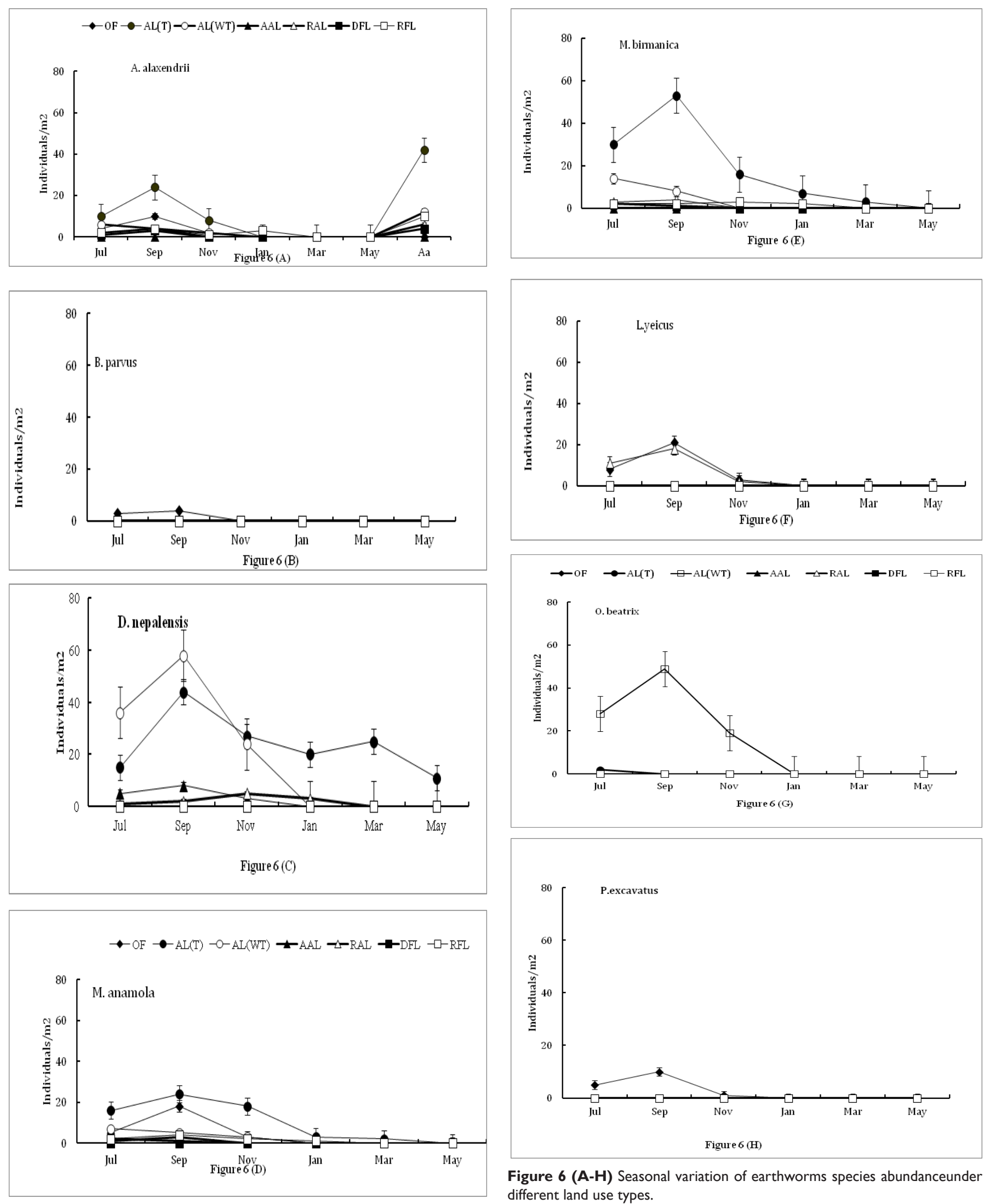

Figure 6 (A-H) Seasonal variation of earthworms species abundanceunder different land use types. 
i. D. nepalensis: Density and biomass varied significantly seasonally in $\operatorname{AL}(\mathrm{T})\left(\mathrm{F}_{0.05,5,12}=83.83\right), \mathrm{AL}(\mathrm{WT})\left(\mathrm{F}_{0.05,5,12}=437.33\right)$, AAL $\left(\mathrm{F}_{0.05,5,12}=16.6\right)$ and in $\operatorname{RAL}\left(\mathrm{F}_{0.05,5,12}=7.53\right)$. The species showed higher population density $\left(\mathrm{q}_{0.05,12,6}=10.56\right)$ and biomass $\left(\mathrm{q}_{0.05,12,6}=\right.$ 9.67) in Sep in $\operatorname{AL}(\mathrm{T})\left(\mathrm{q}_{0.05,12,6}=5.87\right), \operatorname{AL}(\mathrm{WT})\left(\mathrm{q}_{0.05,12,6}=7.22\right)$ and AAL $\left(\mathrm{q}_{0.05,12,6}=7.65\right)$, however it also showed a minor peak of growth during March in AL(T). In RAL it had higher density $\left(\mathrm{q}_{0.05,12,6}=12.78\right)$ and biomass $\left(\mathrm{q}_{0.05,12,6}=6.58\right)$ in July and a minor increase in population was observed in November, though the difference in abundance of the species did not vary significantly between Sep and November.

ii. M. anamola: Population abundance varied significantly seasonally in $\operatorname{AL}(\mathrm{T})\left(\mathrm{F}_{0.05,5,12}=130.5\right)$ and $\mathrm{AL}(\mathrm{WT})\left(\mathrm{F}_{0.05,5,12}=14.93\right)$. At these sites population improved significantly during the $\left(\mathrm{q}_{0.05,12,6}=9.33\right)$ September, however the biomass of these species was higher during November in $\operatorname{AL}(\mathrm{T})\left(\mathrm{q}_{0.05,12,6}=6.65\right)$, AL(WT) $\left(\mathrm{q}_{0.05,12,6}=\right.$ 7.43). Population abundance of M.anamola did not show significant variation seasonally in AAL, RAL and RFL but the biomass of these species was higher during September in AAL $\left(\mathrm{q}_{0.05,12,6}=5.76\right)$, RAL $\left(\mathrm{q}_{0.05,12,6}=6.22\right)$ and $\operatorname{RFL}\left(\mathrm{q}_{0.05,12,6}=5.49\right)$ and declined subsequently.

iii. M.birmanica: Population abundance $\left(\mathrm{F}_{0.05,5,12}=62.32\right)$ and biomass $\left(\mathrm{F}_{0.05,12}=84.45\right)$ of M.birmanica varied significantly seasonally and showed increased population density $\left(\mathrm{q}_{0.05,12,6}=\right.$ 9.02) during September in $\mathrm{AL}(\mathrm{T})$ with decline subsequently. Population abundance did not show seasonal variation in other sites. It showed higher biomass during Sep in $\operatorname{AL}(\mathrm{T})\left(\mathrm{q}_{0.05,12,6}=\right.$ 11.23), $\operatorname{AL}(\mathrm{WT})\left(\mathrm{q}_{0.05,12,6}=8.65\right)$ and $\operatorname{RAL}\left(\mathrm{q}_{0.05,12,6}=10.56\right)$, but in RFL it showed higher biomass during November $\left(\mathrm{q}_{0.05,12,6}=\right.$ 12.67).

iv. L.pussilus: Population abundance varied significantly $\left(\mathrm{F}_{005,512}=\right.$ 206) seasonally in OF and RAL and it had higher density $\left(\mathrm{q}_{0.05,12,6}=112.67\right)$ and biomass $\left(\mathrm{q}_{0.05,12,6}=18.43\right)$ during September in both these sites.

v. O.beatrix: Population abundance varied significantly $\left(\mathrm{F}_{0.05,5,12}=\right.$ 346) seasonally in $\mathrm{AL}(\mathrm{WT})$ and it had higher density $\left(\mathrm{q}_{0.05,12,6}=\right.$ 13.58) and biomass $\left(\mathrm{q}_{0.05,12,6}=15.43\right)$ values during September.

vi. P.excavatus: Population abundance of $\mathrm{P}$. excavatus also varied significantly $\left(\mathrm{F}_{0.05,512}=58.40\right)$ seasonally and had higher $\operatorname{density}\left(\mathrm{q}_{0.05,12,6}=14.54\right)$ and biomass $\left(\mathrm{q}_{0.05,12,6}=16.55\right)$ during the September in OF.

i. Diversity index for earthworm communities between different land use types

The Simpsons Diversity Index within the earthworm communities under different land use types was lowest in AAL and maximum in OF. The diversity index was similar between OF and RAL. Within the agro ecosystem the diversity Index was lower in AL (WT) compared to AL (T), but rehabilitation of degraded ecosystem led to improved diversity Index in RAL and RFL (Figure 7).

\section{j. Earthworm species dominance (\%) (a) abundance (b) biomass (values in parenthesis) within the same land use types}

L. pussilus was dominant numerically in OF but A. alexandri had higher biomass values as compared to other species. At AL(T), $\mathrm{AL}(\mathrm{WT})$ and AAL D. nepalensis was dominant numerically as well having a higher biomass percentage, L. pussilus was dominant numerically at RAL but $D$. nepalensis had higher biomass here. $A$. alexandri was dominant numerically as well as higher biomass values in DFL and RFL but $M$. anamola had higher biomass percentage at the RFL site (Table 6).

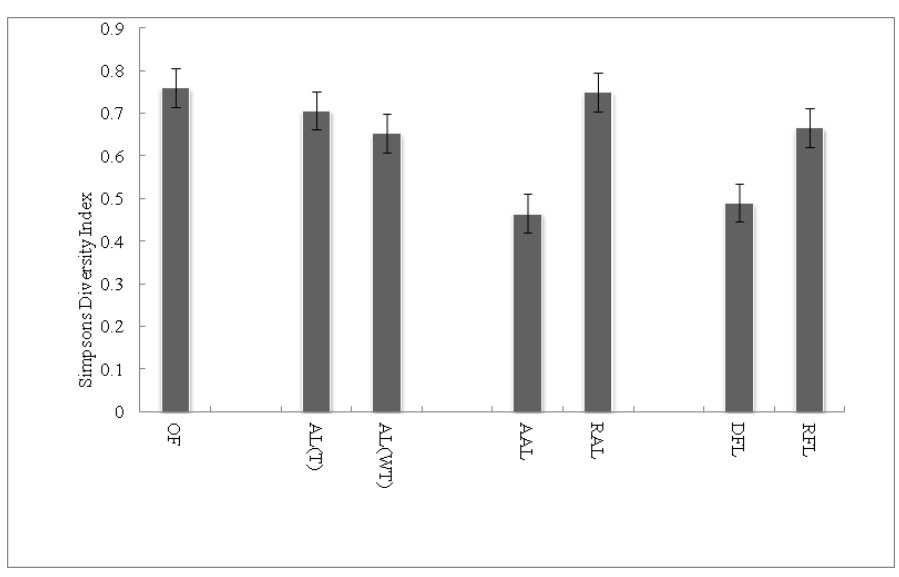

Figure 7 Earthworm species diversity index under different land use changes.

Table 6 Earthworm species dominance (\%) Abundance \& Biomass (Values in parenthesis) within the same land use types in Garhwal Himalayas

\begin{tabular}{|c|c|c|c|c|c|c|c|}
\hline & OF & $A L(T)$ & $\begin{array}{c}\text { AL } \\
\text { (WT) }\end{array}$ & AAL & RAL & DFL & RFL \\
\hline \multirow{2}{*}{$\begin{array}{c}\text { A. } \\
\text { alexandri }\end{array}$} & 16.5 & 11.84 & 4.57 & 0 & 12 & $* 57.15$ & $* 36$ \\
\hline & $(* 39)$ & $(12.7)$ & (6) & & (19) & $(* 57)$ & (29) \\
\hline \multirow{2}{*}{ B.parvus } & 7.22 & 0 & 0 & 0 & 0 & 0 & 0 \\
\hline & (3.1) & (0) & (0) & (0) & (0) & (0) & (0) \\
\hline \multirow{2}{*}{$\begin{array}{c}D . \\
\text { nepalensis }\end{array}$} & 0 & $* 40$ & $* 44.87$ & $* 61$ & 21 & 0 & 0 \\
\hline & 0 & $(* 38)$ & $(* 53)$ & $(* 56)$ & $(* 4 I)$ & 0 & 0 \\
\hline \multirow{2}{*}{$\begin{array}{l}\text { M.ana- } \\
\text { mola }\end{array}$} & 26.8 & 16.9 & 5.71 & 12 & 8 & 0 & 32.14 \\
\hline & (32) & (16) & (6) & (24) & $(16)$ & (0) & $(* 39)$ \\
\hline \multirow{2}{*}{$\begin{array}{l}\text { M.birma- } \\
\text { nica }\end{array}$} & 0 & 30.71 & 8.37 & 27 & 0 & 42.86 & 32.14 \\
\hline & (0) & (33) & (II) & (20) & (3I) & (43) & (32) \\
\hline \multirow{2}{*}{ L.pussilus } & *32.99 & 0 & 0 & 0 & $* 59$ & 0 & 0 \\
\hline & (3I) & (0) & (0) & & $(12)$ & (0) & (0) \\
\hline \multirow{2}{*}{ O.beatrix } & 0 & 0.56 & 36.5 & 0 & 0 & 0 & 0 \\
\hline & (0) & $(0.3)$ & (24) & (0) & (0) & (0) & (0) \\
\hline \multirow{2}{*}{$\begin{array}{l}\text { P.excava- } \\
\text { tus }\end{array}$} & 16.5 & 0 & 0 & 0 & 0 & 0 & 0 \\
\hline & $(10.1)$ & (0) & (0) & (0) & (0) & (0) & (0) \\
\hline
\end{tabular}

k. Morisita's index of similarity for earthworm communities between different land use types

Morrisitas index of similarity indicated that the earthworm community in AL (T) was more similar to AAL than AL (WT). Rehabilitation of degraded agro ecosystem showed that the community structure of RAL was more similar to the OF where as community structure between RFL and DFL were closer to one another (Table 7). 
Table 7 Morisita's index of similarity for earthworm communities between different land use types

\begin{tabular}{|c|c|c|c|c|c|c|c|}
\hline & OF & $A L(T)$ & AL(WT) & AAL & RAL & DFL & RFL \\
\hline OF & I & 0.248 & 0.08 & $\begin{array}{c}0 \\
.088\end{array}$ & 0.72 & 0.252 & 0.51 \\
\hline$A L(T)$ & & I & 0.688 & 0.91 & 0.32 & 0.491 & 0.625 \\
\hline AL(WT) & & & I & 0.75 & 0.273 & 0.181 & 0.15 \\
\hline AAL & & & & I & 0.315 & 0.24 & 0.311 \\
\hline RAL & & & & & 1 & 0.142 & 0.175 \\
\hline DFL & & & & & & I & 0.81 \\
\hline RFL & & & & & & & I \\
\hline
\end{tabular}

\section{Correlation coefficient for earthworm communities between different land use types}

A significant correlation coefficient was observed between earthworm population and soil moisture and temperature. $A$. alexandri was positively correlated to soil moisture $(P<0.05)$ and temperature $(P<0.05)$. In AL(WT), RAL, DFL. B. parvus, and $L$. pussilus showed positive correlation $(P<0.05)$ to soil moisture and temperature, $P$. excavatus was positively correlated to moisture $(P<0.05)$ but did not show any co relation to soil temperature. $D$. nepalensis was positively related $(P<0.05)$ to soil moisture in $\mathrm{AL}$ (T), AL (WT) and RAL but it did not show any correlation with soil moisture in AAL. M anamola was positively related to soil moisture ( $P<0.01)$ and temperature $(P<0.01)$ in AL (WT) AAL and RAL but in AAL it did not show any correlation to soil moisture. In AL (WT) and AAL M. birmanica exibited similar trend as M. anamola however in DFL $(P<0.01)$ and RFL $(P<0.05)$ it showed positive correlation to soil moisture only. $O$. beatrix showed positive correlation to soil temperature $(P<0.01)$ in AL (T), AL (WT), but it did not show any relation to soil moisture (Table 8 ).

Table 8 Correlation coefficient(r) for soil moisture (M\%); temperature $\left(\mathrm{T}\left({ }^{\circ} \mathrm{C}\right)\right.$ and earthworm species abundance in Garhwal Himalaya

\begin{tabular}{|c|c|c|c|c|c|c|c|c|c|c|c|c|c|c|c|c|}
\hline & \multicolumn{2}{|c|}{ A. alexandri } & \multicolumn{2}{|c|}{ B.parvus } & \multicolumn{2}{|c|}{ D. nepalensis } & \multicolumn{2}{|c|}{ M.anamola } & \multicolumn{2}{|c|}{ M.birmanica } & \multicolumn{2}{|c|}{ L.pussilus } & \multicolumn{2}{|c|}{ O.beatrix } & \multicolumn{2}{|c|}{ Pexcavatus } \\
\hline & $\begin{array}{c}M \\
(\%)\end{array}$ & $\begin{array}{c}\mathrm{T} \\
\left({ }^{\circ} \mathrm{C}\right)\end{array}$ & $\begin{array}{c}M \\
(\%)\end{array}$ & $\begin{array}{c}\mathrm{T} \\
\left({ }^{\circ} \mathrm{C}\right)\end{array}$ & $\begin{array}{c}M \\
(\%)\end{array}$ & $\begin{array}{c}\mathrm{T} \\
\left({ }^{\circ} \mathrm{C}\right)\end{array}$ & $\begin{array}{l}M \\
(\%)\end{array}$ & $\begin{array}{c}\mathrm{T} \\
\left({ }^{\circ} \mathrm{C}\right)\end{array}$ & $\begin{array}{c}M \\
(\%)\end{array}$ & $\begin{array}{c}\mathrm{T} \\
\left({ }^{\circ} \mathrm{C}\right)\end{array}$ & $\begin{array}{c}M \\
(\%)\end{array}$ & $\begin{array}{c}\mathrm{T} \\
\left({ }^{\circ} \mathrm{C}\right)\end{array}$ & $\begin{array}{c}M \\
(\%)\end{array}$ & $\begin{array}{c}\mathrm{T} \\
\left({ }^{\circ} \mathrm{C}\right)\end{array}$ & $\begin{array}{l}M \\
(\%)\end{array}$ & $\begin{array}{c}\mathrm{T} \\
\left({ }^{\circ} \mathrm{C}\right)\end{array}$ \\
\hline OF & -0.03 & 0.30 & $* * 0.96$ & $* * 0.95$ & A & $A$ & 0.34 & $0.4 I$ & A & A & $* 0.89$ & $* 0.87$ & A & A & $* * 0.92$ & $* 0.9$ \\
\hline$A L(T)$ & -0.03 & 0.40 & A & A & $* 0.88$ & $* 0.84$ & $* * 0.97$ & 0.55 & $* * 0.98$ & $* 0.96$ & $A$ & A & 0.62 & $* * 0.92$ & A & $A$ \\
\hline AL(WT) & $* 0.88$ & $* 0.87$ & A & A & $* 0.85$ & $* 0.87$ & $* * 0.99$ & $* 0.87$ & 0.56 & 0.18 & $A$ & $A$ & 0.58 & $* * 0.95$ & A & $A$ \\
\hline AAL & A & A & A & A & 0.19 & $* 0.8 \mathrm{I}$ & $* * 0.96$ & $* 0.97$ & $* * 0.97$ & $* 0.95$ & $A$ & A & A & $A$ & A & $A$ \\
\hline RAL & $* * 0.98$ & $* 0.95$ & A & A & $* 0.88$ & $* 0.83$ & $* * 0.98$ & $* 0.96$ & A & $A$ & $* 0.85$ & $* 0.89$ & A & A & $A$ & $A$ \\
\hline DFL & $* * 0.97$ & $* 0.96$ & $A$ & A & $A$ & $A$ & $A$ & $A$ & $* * 0.97$ & $A$ & $A$ & $A$ & $A$ & A & $A$ & $A$ \\
\hline RFL & 0.31 & 0.27 & $A$ & A & $A$ & $A$ & -0.28 & -0.35 & $* .85$ & -0.38 & $A$ & A & A & $A$ & A & $A$ \\
\hline
\end{tabular}

*indicates $P<0.05$, **indicates $P<0.01$

\section{Discussion}

Consequences of deforestation arise from site degradation leading to strong modification of soil properties this in turn can significantly affect both incidence and abundance of soil macro fauna. Earthworm communities are more directly altered by this changes..$^{19}$ Endemic and exotic species co existed in the study area following deforestation and intensive cultivation. That native species dominate the undisturbed sites and disturbance and degradations leads to invasion by the exotic species $^{20}$ holds true in our study. The sites under study represented the degraded areas as none of the species reported from the present experimental plots were endemic to the region, all the species are either peregrine exotic or peregrine endemic to the area as many of the endemic species of this region probably exterminated during the last Quaternary Glaciation. ${ }^{21}$ The elimination of old secondary forest and its replacement with agroecosystem also led to changed species composition due to altered habitat with peregrine exotics $M$. birmanica, $O$. beatrix and peregrine natives $D$ nepalensis replacing peregrine exotics $B$. parvus, and natives $L$. pussilus and $P$. excavates in AL (T) and in AL (WT), similar results have also been shown through the studies. ${ }^{22}$ Extreme degradation of agriculture ecosystems due to faulty land management practices probably led to the loss of peregrine exotics $A$. alaxandri, M. anamola and $O$. beatrix in AAL as has also been shown through the studies ${ }^{19}$ in land use types in Northern 
Kwazulu Natal South Africa. The disappearance of peregrine exotics A. alaxandri and peregrine natives L. pussilus in RAL could probably be related to changed vegetation and edaphic conditions in RAL as has also been reported by Fragoso $\mathrm{C}$ et al ${ }^{23}$ for earthworm communities in disturbed natural systems of tropical east Mexico and rehabilitation of RAL through various trees and crops probably led to invasion of peregrine exotic M. birmanica and M. anamola in these area. Higher level of degradation leading to replacement of OF to degraded forest land led to loss of exotic B. parvus, M. anamola and natives L. pussilus, P. excavatus. Resistance to invasion by endemic species in DFL and RFL could be a function of physical and chemical characteristics of the site $^{24}$ and the unsuitability of the habitat probably impeded the invasion by the endemic species in the ecosystems under study. ${ }^{25}$ The absence of original species composition in RAL and RFL as compared to OF even after a period of 15 to 20 years suggest that this is probably still the secondary successional stage over a time scale of 15 years. ${ }^{26}$

\section{m. Total density and biomass}

Land-use alteration generally results in changes of vegetation and these changes have a significant effect on soil macrofauna. ${ }^{4}$ Study done by ${ }^{19}$ in South Africa showed most land uses supported between five and seven species. but the number of species present at our sites were lower ranging between 2 to 5 . The statement that earthworm populations in cultivated lands are generally lower than those found in undisturbed habitats ${ }^{27}$ does not hold true in our studies, the traditional agriculture probably have a positive effect on earthworms through improved food supply as a result of recycling of crop residues, and organic manure added to the soil resulting in loosening of soil to an extent that facilitates burrowing by earthworms. ${ }^{28}$ This also explains the increased abundance and biomass of earthworm in $\mathrm{AL}(\mathrm{WT})$ as compared to OF. With lower bulk density and higher carbon percentage, coupled with reduced disturbance this effect was more prominent in $\mathrm{AL}(\mathrm{T})$. In RAL the supplemental irrigation and organic manure along with the planted trees following traditional farming practices favored the increase in total earthworm density as well as biomass. The smaller community under AAL and DFL than OF is attributable to loss of species when the land was cleared and cultivated. More stress full environment in DFL as compared to AAL due to heavy grazing pressure and lower soil moisture ${ }^{2}$ probably caused significant difference in the density and biomass of earthworm between AAL and DFL. In the present study the numerical abundance of earthworms in OF is lower compared to similar land use type from Kumoan Himalayas. Besides variation in ecological characteristics probably the land use history of the ecosystems contributes to this variation, the sub-temperate climate in the study area and the relatively lower inputs of organic matter apparently provide poor conditions for earthworm populations to flourish. As a result total numbers were very low ranging from 8 to $348 \mathrm{~m}-2$ as compared to high ranging from 250 to $2400 \mathrm{~m}-2$ in Northern Kwazulu Natal South Africa. ${ }^{19}$ Earthworm biomass showed broadly similar trends with land use to those for abundance.

\section{n. Interhabitat variation}

Interactions between species and sensitivity to ecological factors, presence or absence of and changes in ground vegetation composition are known to affect the composition of earthworm communities through changes in the distribution and the quality of litter, soil climate, and water availability. The presence of litter layer and lower perturbation pressure probably explains the numerical dominance of L. pussilus in the $\mathrm{OF}$ and the higher biomass of A. alexandri could be due to the larger size of the earthworm. B. parvus, L. pussilus and $P$. excavatus are litter-associated taxa which were more directly affected by OF clearance and the resulting decrease in available litter, thus explaining their disappearance in the changed ecosystems, however improved soil moisture and temperature as well as input of organic matter in RAL could probably be favorable factor for decolonization and dominance of L. pussilus. A. alexandri has wider ecological amplitude occurring under all land use types. Major determinants of earthworm communities' structure in an agro ecosystem are the quantity and quality of organic matter added, soil type and the perturbation pressure. ${ }^{29}$ With better adaptation and tolerance to various disturbances during agro forestry practices. D. nepalensis was confined only to agroecosystems and was numerically dominant during cropping in AL (WT), in AL (T) and also in AAL. M. anamola was more directly affected due to perturbation pressure and soil degradation caused through conversion of forest to agro ecosystem, The increased population density of $A$. alexandri, D. nepalensis and M. anamola in AL (T) as compared to AL(WT) is likely due to amelioration of the surface soil temperature and moisture by litter, and tree leaf biomass incorporated into the soil. The lower density and biomass of $D$. nepalensis under AL(WT) as compared to AL(T) could be the result of perturbations caused to the soil due to agricultural practices besides here the decline in D. nepalensis abundance in AAL and its subsequent increase in RAL could probably be because of lower soil bulk density and higher carbon percentage here and also because this land use categories maintain a year round canopy and litter layer. ${ }^{2}$ The lower biomass of $A$. alexandri in RFL may be due to species specific competition between $M$. anamola and $A$. alexandri as both occupy the same niche. Most changes in the distribution of earthworm species are explained by microclimate variations in soils thus low soil water content, high soil temperature, and incident radiation probably resulted in the decline in abundance and biomass of $M$. birmanica. in AAL and DFL as has also been shown through the studies of ${ }^{30}$ in the land use systems in eastern Zambia however improvement of soil conditions through the rehabilitation of forested land led to recurrence of this species. The traditional farming practices under rain fed conditions probably favored the population of $O$. beatrix species and thus explains its presence in agro ecosystem only.

\section{o. Similarity index}

Our results show that the AAL remains closer to the AL (T) than to the forest, because in these land use types the overall vegetation diversity remains low corresponding to a low diversification of the organic resources thus explaining the similarity between the communities in land use types. ${ }^{31}$ The shift in plant composition in RAL resulted in a shift in organic input from a below ground pattern in AAL to an above and below ground input here. This increase in above ground litter input created habitat in the plantation floor similar to that of $\mathrm{OF}$ and this probably was the reason for community structure of RAL to similar to the OF as has also been shown through the studies done by workers ${ }^{32}$ who suggested that the community structure under tree plantations is typically similar to that under native forest. The rehabilitation of DFL only caused an increase in the abundance of earthworm species in RFL resulting in community structure of RFL and DFL being closer to one another.

\section{p. Functional guild}

The size and species composition of earthworm communities are important because any shifts in earthworm community may result in significant changes in soil properties, epigeic earthworms, which 
usually inhabit upper soil and litter layers, may be more exposed than endogeic and anecic species that live primarily in subsurface soil. The conversion of OF to agro ecosystems led to a shift in functional categories from epigeic dominated species community to endogiec and anecic dominated composition, as has also been shown through studies of ${ }^{33}$ where the loss of the surface litter layer when rain forest is converted to agricultural use resulted in a dramatic decrease in the number of epigeic and anecic species and increase in numbers by endogeics species. The epigeics are litter-associated and thus were more directly affected by forest clearance and the resulting decrease in available litter leading to their loss in all the experimental plots except in RAL where with the deposition of litter the epiges recurred. $P$. excavates and $B$. parvus species cannot therefore survive in areas with less plant cover and litter availability and thus can be said to be bioindicator of land use that leads to these conditions. Anecic species need plant litter and specific microclimatic conditions in the soil thus the cropping activities with the removal of litter layer in AL (WT) prior to rice crop plantation resulted in decline of the anecics here. The increase in above ground litter input in AL (T) created microhabitat in the below canopy promoting the colonization of both endoges and anecic species. Further anecics are generally sparse in tropical environments, ${ }^{34}$ the experimental studies in the rehabilitated plots by Butt KR et al. ${ }^{35}$ have shown anecics to be slow colonizers in the reclaimed sites and this could probably explain their lower density in the RAL and RFL. Endogeics being geophagus, their predominance in the AL (T), AL (WT) AAL and RAL, could be because probably these habitats offered favorable base resource to the species which migrated from the surrounding plots to colonize and establish themselves in the new habitats. ${ }^{36,37}$ Dominance of endogeics in the disturbed habitats has also been shown through the studies of. ${ }^{38,39}$ As a consequence, while epigeics does not significantly alter the soil surface, casts produced by endogeics highly modify soil surface properties.

\section{q. Diversity index}

As reported in our studies conversion of OF to other land use types resulted in lower species diversity, similar result were also obtained through the studies of ${ }^{40}$ where conversion of forests to pastures resulted in decline of earthworm species diversity. Rehabilitation of these ecosystems in RAL and RFL resulted in improved diversity index of the community structure, this increase in earthworm diversity could probably be related to a shift in organic input from a below ground pattern in AAL and DFL to an above and below ground input in RAL and RFL. ${ }^{41}$ The lower overall vegetation diversity in AAL probably corresponded to a very low diversification of the organic resources and this can explain a lower diversity of earthworms here as low resource diversity leads to impoverished species diversity. ${ }^{38}$

\section{r. Seasonal variation}

Seasonal variation has been shown for macro faunal assemblages for temperate, ${ }^{42}$ for tropical ${ }^{12}$ and for semiarid region, ${ }^{43}$ similar seasonal rhythm for all the species was also observed in our studies. Earthworm exhibit temporal variability, population density and biomass as well as the average depth of an organisms' position in the soil profile is greatly affected by soil temperature and humidity. ${ }^{44,45}$ such seasonal rhythms of soil macro fauna were clearly expressed in the experimental land use type. Large differences in the number of earthworms were found in the different seasons highest catches were in monsoon, with lower numbers in winter and a large reduction in summer. Many soil organisms display strong seasonality in their life cycles ${ }^{46}$ Few earthworms were found in summer compared to monsoon months, suggesting that all species hatch during early monsoon grow to adulthood over the monsoon period and decline in winter months, the lower mean catches in summer can be attributed to a response to drought by some species, the increase in the population density and the biomass of all earthworm species during the rainy season could be attributed to better soil moisture and temperature condition which favored the growth and maturity of earthworms. ${ }^{47}$ Seasonal temperature variations commonly induce vertical movements of earthworms in as soil profile $\mathrm{e}^{48,49}$ as was also observed in D. nepalensis in the $\mathrm{AL}(\mathrm{T})$ which retreated to deeper soil ${ }^{50}$ to escape lower temperature and draught by diapausing during winter.

\section{Conclusion}

This study has shown that earthworm communities are directly affected by alteration of land use patterns. The numbers of species present at our sites ranged between 2 to 5 . All the ecological categories such as endemic and exotics co-existed in the study area following deforestation and intensive cultivation, and the disturbance and degradations led to invasion by the exotic species and the native species dominated the undisturbed sites. The sites under study represented the degraded areas and none of the species reported from the present experimental plots were endemic to the region, all the species are either peregrine exotic or peregrine endemic to the area, as many of the endemic species of this region probably exterminated during the last Quaternary Glaciation. The presence of litter layer and lower perturbation pressure resulted in the numerical dominance of epigeic $\mathrm{L}$. pussilus in the Oak forest (OF) and the higher biomass of A. alexandri may be because of the larger size of the earthworm. Litter-associated taxa (Epigeics) such as B. parvus, L. pussilus and P. excavatus are more directly affected by primary OF clearance and the resulting decrease in available litter, thus explaining their disappearance in the changed ecosystems. However improved soil moisture and temperature as well as input of organic matter in rehabilitated agricultural land (RAL) were probably one of the favorable factor for decolonization and dominance of epigeic $L$. pussilus. Endogeic species probably are not much affected by deforestation and degradation process and therefore A. alexandri had a wider ecological amplitude occurring under all land use types, however conversion of primary OF to other land use types resulted in lower species diversity. Our results show that the earthworm diversity in abandoned agriculture land (AAL) remains closer to the AL(T) than to the forest because in these land use types the overall vegetation diversity remains low corresponding to a low diversification of the organic resources thus explaining the similarity between the earthworm communities in land use types. All the species identified at study sites showed seasonal rhythmic pattern.

\section{Acknowledgements}

The research was financially supported by TSBF-SARNET programme. Thanks are due to Dr JM Julka (Emeritus Scientist) of Zoological Survey of India, Govt. of India for taxonomic identification of the earthworm species. The authors acknowledge the help extended by the co-ordination unit based at JNU New Delhi for providing the necessary literature.

\section{Conflicts of interest}

There is no financial or any conflict of interest exists. 


\section{References}

1. Semwal RL, Maikhuri RK, Rao KS, et al. Crop Productivity under Differently Lopped Canopies of Multipurpose Trees in Central Himalaya in India. Agroforestry Systems. 2002;56(1):57-63.

2. Maikhuri RK, Rao KS, Semwal RL. Rehabilitation of Degraded Lands through Participatory Approach and Action Research: A case study from Central Himalaya. Asscociation Annual Journal. 2001;1(2):36-45.

3. Maikhuri RK, Semwal RL, Rao KS. Rehabilitation of Degraded Community Lands for Sustainable Development in Himalayas: A case study in Garhwal Himalaya, India. International Journal of Sustainable Development \& World Ecology. 1997(4):192-203.

4. Pauli N, Barrios E, Conacher AJ, et al. Soil Macrofauna in Agricultural Landscapes Dominated by the Quesungual Slash-and-Mulch Agroforestry System, Western Honduras. Applied Soil Ecology. 2010;47(2):119-132.

5. Barrios E. Soil Biota. Ecosystem Services and Land Productivity. Ecology Economics. 2007;64(2):269-285.

6. Tao HH, Slade EM, Willis KJ, et al. Effects of Soil Management Practices on Soil Fauna Feeding Activity in an Indonesian oil Palm Plantation. Agriculture, Ecosystems \& Environment. 2016;218:133-140.

7. Baretta D, Bartz MLC, Fachini I, et al. Soil Fauna and its Relation with Environmental variables in Soil Management Systems. Revista Ciencia Agronomica. 2014;45(5):1806-6690.

8. Capowiecz Y. Differences in Burrowing Behaviour and Spatial Interaction between the two Earthworm Species Aporrectodea nocturna and Allolobophora chlorotica. Biology and Fertility of Soils. 2000;30(4):341-346

9. Briones MJ, Mascato R, Mato S. Autoecological Study of some Earthworm Species (Oligochaeta) by Means of Ecological Profiles. Pedobiologia. 1995(39):97-106.

10. Babel U, Ehrmann O, Krebs M. Relationships between earthworms and some plant species in a meadow. Soil Biology and Biochemistry. 1992;24(12):1477-1481.

11. Jimenez JJ, Moreno AG, Lavelle P, et al. Population Dynamics and Adaptive Strategies of Martiodrilus carimaguensis (Oligochaeta, Glossoscolecidae), A native species from the well-drained savannas of Colombia. Applied Soil Ecology. 1998;9(1-3):153-160.

12. Rossi JP, Blanchart E. Seasonal and Land-Use Induced Variations of Soil Macrofauna Composition in the Western Ghats, Southern India. Soil Biology \& Biochemistry. 2005;37(6):1093-1104.

13. Rao PN, Pati UC. Geology and Tectonics of Bhilangana Valley and its Adjoining Parts, Garhwal Himalaya with Special Reference to the Main Central Thrust. Himalayan Geology. 1980;10:220-237.

14. Okalebo JR, Gathua KW, Woomer PL. Laboratory Methods of Soil and Plant Analysis: A Working Manual. Kenya: ROSTA; 1994. 88 p.

15. Bouyoucos GJ. A Recalibration of the Hydrometer Method for making Mechanical Analysis of the Soil. Agronomy Journal. 1951;43: 434-438.

16. Walkey A, Black IA. An Examination of Degtjareff Method for Determining Soil Organic Matter and a Proposed Chromic Acid Titration Method. Soil Science. 1934;37(1):29-38.

17. Anderson JM, Ingram JS. Tropical Soil Biology and Fertility: A Handbook of Methods. UK: CAB International;1993:221.

18. Zar JH. Biostatistical Analysis. USA: Prentice-Hall Inc; 1974:621.

19. Steinwand M, Steiner BCS, Seebe GUH, et al. Effects of Alpine LandUse Changes: Soil Macrofauna Community Revisited. Ecology and Evolution. 2017;7(14):5389-5399.
20. Korell L, Lang BR, Hensen I, et al. Interaction count: plant origin, herbivory and disturbance jointly explain seedling recruitment and community structure. Scientific Reports. 2017;7:82-88.

21. Julka JM, Paliwal R. Distribution of Earthworms in Different Agroclimate Regions of India. In: Ramakrishnan PS, Saxena KG, et al. editors. Soil Biodiversity: Ecological processes and Landscape Management. India: Oxford and IBH Publishing Co. Pvt. Ltd; 2005.

22. Myers N, Knoll A. The Biotic Crisis and the Future of Evolution Proceedings of the National Academy of Sciences of United States of America. 2001;98(10):5389-5392.

23. Fragoso C, Fernandez PR. Earthworms from South Western Mexico, New Acanthodriline genus and species (Megascolicidae-Oligochaeta). Megadrilogica. 1994;6(1):1-12.

24. Hendrix PF, Baker GH, Callaham MA, et al. Invasion of Exotic Earthworms into Ecosystems Inhabited by Native Earthworms. Biological Invasion. 2006;8(6):1287-1300.

25. Hendrix PF, Bohlen P. Exotic earthworm invasion in North America: Ecological and Policy Implication. Bioscience. 2002;52(9):801-811.

26. Folgarail PJ, Thomas F, Desjardins T, et al. Soil Properties and the Macrofauna Community in Abandoned Irrigated Rice Fields of North Eastern Argentina. Biology and Fertility of Soils. 2003;38(6):349-357.

27. Tunira B, Pradeep K, Rakesh M, et al. Effect of Application of Vermicompost and conventional Compost Derived from Different Residues on Pea Crop Production and Soil Faunal Diversity in Agricultural System in Garhwal Himalayas India. Natural Science. 2014;6(6):433-446.

28. Lagerlof G, Goffre B, Vincent C. The Importance of Field Boundaries for Earthworms in the Swedish Agriculture Landscape. Agriculture Ecosystem Environment. 2002;89(1-2):91-103.

29. Fraser PM. The Impact of Soil and Crop Management Practices on Soil Macrofauna. In: Pankhurst CE, Doube MM, Gupta VSR, et al. editors. Soil Biota Management in Sustainable Farming Systems, Transactions of 15 ${ }^{\text {th }}$ World Congress of Soil Science. Mexico: Acapulco; 1994(4a):55-56.

30. Sileshi G, Mafongoya P. Variation in Macrofauna Communities under Contrasting Land Use Systems in Eastern Zambia. Applied Soil Ecology. 2006;33(1):49-60.

31. Basu P, Blanchart E, Lepage M. Termite (Isoptera) Community in the Western Ghats, South India: Influence of Anthropogenic Disturbance of Natural Vegetation. European Journal of Soil Biology. 1996;32(3):113121.

32. Fragoso C, Kanyonyo J, Moreno A, et al. A Survey of Tropical Earthworms: Taxonomy, Biogeography and Environmental Plasticity. In: Lavelle P, Brussaard L, Hendrix P, editors. Earthworm Management in Tropical Agroecosystems. UK: CABI;1999:1-26.

33. Fragoso C, Lavelle P. Earthworm Communities of Tropical Rain Forests. Soil Biology and Biochemistry. 1992;24(12):1397-1408.

34. Barrios I, Lavelle P, Brossard M, et al. Ecology of Earthworm Species with Large Environmental Tolerance and/or Extended Distributions. In: Lavelle P, Brussaard L, Hendrix P, editors. Earthworm Management in Tropical Agroecosystems. UK: CABI;1999:57-85.

35. Butt KR, Lowe CN, Frederickson J, et al. The Development of Sustainable Earthworm Population at Calvert Landfill site, UK. Land Degradation and Development. 2004;15(1): 27-36.

36. Pizl V. Earthworm Succession in Afforested Colliery Spoils Heaps in the Sokolov Region, Czech Republic. Restoration Ecology. 2001;9(4):359364.

37. Winsome T, Epstein L, Hendrix PF, et al. Competition between Native 
and Exotic Earthworms Species in California Grassland. Applied Soil Ecology. 2006;32(1):38-53.

38. Blanchart E, Julka JM. Influence of Forest Disturbance on Earthworm (Oligochaeta) Communities in the Western Ghats (South-India). Soil Biology and Biochemistry. 1997;29(3-4):303-306.

39. Bhadauria T, Ramakrishnan PS. Impact of Land Use Land Cover Change on Earthworm Community Structure in India In: Ramakrishnan PS, Saxena KG, Swift MJ, et al. editors. Soil Biodiversity: Ecological processes and Landscape Management. India: Oxford and IBH Publishing Co. Pvt. Ltd; 2005.

40. Rombke J, Verhaagh M. About Earthworm Communities in a Rain Forest and an Adjacent Pasture in Peru. Amazoniana. 1992;12(1):29-49.

41. Zou X, Gonzalez G. Changes in Earthworm Density and Community Structure during Secondary Succession in Abandoned Tropical Pastures. Soil Biology \& Biochemistry. 1997;29(3-4):627-629.

42. Berg MP, Kniese JP, Bedaux JJM, et al. Dynamics and Stratification of Functional Groups of Micro and Mesoarthropods in the Organic Layer of a Scots Pine Forest. Biology and Fertility of Soils. 1998;26(4):268-284.

43. Miranda ED, Pinero FS, Megias GA. Soil Macro Invertebrate Fauna of a Mediterranean Arid System: Composition and temporal changes in the assemblage. Soil Biology and Biochemistry. (2007);39(8):1916-1925.
44. Fayolle L, Michaud H, Cluzeau D, et al. Influence of Temperature and Food Source on the Life Cycle of the Earthworm Dendrobaena veneta (Oligochaeta). Soil Biology \& Biochemistry. 1997;29(3-4):747-750.

45. Dibog L, Eggleton P, Forzi F. Seasonality of Soil Termites in a Humid Tropical Forest, Mbalmayo, Southern Cameroon. Journal of Tropical Ecology. 1998;14(6):841-849.

46. Measey GJ, Gower DJ, Oommen OV, et al. A Subterranean Generalist Predator: Diet of the soil-dwelling caecilian Gegeneophis ramaswamii (Amphibia; Gymnophiona; Caeciliidae) in southern India. Comptes Rendus Biologies. 2004;327(1):65-76.

47. Campana C, Gauvin S, Ponge JF. Influence of Ground Cover on Earthworm Communities in an Unmanaged Beech Forest: linear gradient studies. European Journal of Soil Biology. 2002;38(2):213-224.

48. Luxton M. Studies on the Orbatid Mites of a Danish Beech wood Soil IV, Developmental Biology. Paedobiologia. 1981;21:312-340.

49. Didden WAM. Ecology of Terrestrial Enchytraedae. Pedobiologia. 1993;37: 2-29.

50. Morgan JE, Morgan AJ. Seasonal Changes in the Tissue-Metal (Cd, $\mathrm{Zn}$ and $\mathrm{Pb}$ ) Concentrations in two Eco-physiologically Dissimilar Earthworm Species: Pollution-monitoring implications. Environmental Pollution. 1993;82(1):1-7. 